\title{
EFFECT OF DRYING METHODS ON CRAMBE (Crambe abyssinica HOCHST) SEED COAT PIGMENTATION AND ON OIL AND BIODIESEL QUALITY ${ }^{1}$
}

Doi:http://dx.doi.org/10.1590/1809-4430-Eng.Agric.v36n6p1167-1175/2016

\section{MAGNUN A. P. DA SILVA ${ }^{2 *}$, MARCO A. M. BIAGGIONI ${ }^{3}$, FELIPE C. S. SPEROTTO ${ }^{3}$, ANA C. MACEDO ${ }^{3}$, FERNANDO J. B. BRANDÃO ${ }^{3}$}

${ }^{2 *}$ Corresponding author. Universidade Estadual Paulista "Júlio de Mesquita Filho"/ Botucatu - SP, Brasil. E-mail: penariol@gmail.com

ABSTRACT: The objective of this study was to evaluate the effect of different drying methods on seed coat pigmentation and quality of oil and biodiesel extracted from crambe. The experimental design was completely randomized with five treatments and four replications, totaling 20 plots. The treatments consisted of drying with heated air, natural air, ground, in the shade and in the plant. Physical and chemical analyzes were performed to verify the quality of grain, oil and biodiesel. The largest amounts of chlorophyll $\mathrm{a}$ and $\mathrm{b}$ and green beans and the lowest oil content were found in artificial drying with heated air. It was concluded that the drying in the plant presented grains and oil of better quality, but do not interfering in the quality of biodiesel, which has met the standards required by the ANP.

KEYWORDS: chlorophyll, biofuels, oilseed.

\section{INTRODUCTION}

The Brazilian energy matrix is characterized by high share of renewable energies in its composition, with $44.1 \%$ coming from sources such as hydropower and biomass (BRASIL, 2012). The share of biofuels such as biodiesel can contribute to the increase of renewable energy in the composition of the energy matrix (SILVA et al., 2013). Studies are being directed to vegetable oils, to be a source of obtaining lower cost and have higher energy density than the processed vegetable oils, and present less risk of environmental contamination (DELALIBERA et al., 2012)

In the search for raw materials for the production of biodiesel, it highlights factors such as oil content; productivity; production system; crop cycle, oil quality, among others. It is believed that being a winter crop the crambe has high potential as a raw material for biodiesel besides acting in crop rotation (PITOL et al., 2010).

The crambe culture shows from harvesting to its pre-processing lowest costs when compared to other sources such as canola, sunflower, and soybean (JASPER et al., 2010), additionally, crambe enables the continuity of biodiesel production and utilization in the industry for being an off-season alternative, since the most used oils for this purpose are from spring and summer cycles (COLODETTI et al., 2012).

The crambe (Crambe abyssinica Hochst) originates from Ethiopia, belonging to the family of crucifers, of annual cycle. Displays height between 70 and $90 \mathrm{~cm}$, bloom on 35 days after sowing, and has oil content between 35 and $60 \%$ of grain formation. The culture is distinguished by rusticity and precocity, able to dry and cold regions; its cultivation is fully mechanized, using traditional equipment for grain production (PITOL et al. 2010). BRANDÃO et al. (2013) studying agricultural productivity in crambe crop obtained $1,428.98 \mathrm{~kg} \mathrm{ha}^{-1}$.

For biofuel production, renewable sources with the greatest potential are vegetable oils and animal fat (ROCHA et al., 2013), in this context, crambe, for being a crop with high oil content, became promise in biodiesel production.

\footnotetext{
${ }^{1}$ Extracted from the first author's Master's dissertation

${ }^{3}$ Universidade Estadual Paulista "Júlio de Mesquita Filho" / Botucatu - SP, Brasil.

Received in: 4-16-2014

Accepted in: 8-2-2016
} 
The crambe culture present no uniform ripening grain, and the first fruit formed remain attached to the plant until the last fruit reach maturity, resulting in grains of various stages of development present in the plant simultaneously (OLIVA et al., 2012 ).

The presence of green beans cause damage to the oil and biodiesel production sector due to the oil be reduced in its oxidative stability (PÁDUA et al., 2009a). The darkening oil color is undesirable having its production cost increased with the removal of the green pigment from grains (PÁDUA et al., 2009b).

According to FUKUSHIMA \& LANFER-MARQUEZ (2000) in Canada and the United States, the incidence of green beans is observed in canola (Brassica napus L.), resulting in problems especially for the oil extraction industry. Thus, the green pigment is considered a quality parameter for that crop.

The post-harvest procedures are of great importance in the maintenance of grain quality, and consequently the oil. Before the extraction process, it is necessary to carry out the stripping, cleaning and drying. For crambe, the processing are not different from other oilseeds; the oil can be extracted by mechanical pressing or by solvent (SILVA et al., 2013).

Among the post-harvest procedures carried out, drying is an important operation which allows an early harvest, in this way; it can avoid long periods in the field, thus preventing damage due to weather conditions, to pests and diseases, reducing the water content to the point of optimum storage (OLIVA et al., 2012).

The drying is a process that can compromise the quality of the grains. Improperly performed, this step that aims to reduce the grain water content can result in significant production losses (OLIVA et al., 2012).

Factors such as the content of free fatty acids, leached content and percentage of green beans can help analyze the quality of the grain after drying. The content of free fatty acids is a reliable analysis because identifies the deterioration of the grain even in its initial state. The electrical conductivity, which quantifies the leaching rate, becomes useful, since by this test it is possible to detect deterioration in the cell walls membranes (SILVA et al., 2013).

The percentage of green beans is related to the chlorophyll content in the grains and in the oil. It is estimated that rapid drying in artificial dryer contributes of staying green beans, because it contributes to chlorophyll retention. On the other hand, for drying in the field with the effect of sunlight, there may be a further degradation of chlorophyll, leaving the grains with lower chlorophyll content, and consequently with lower percentage of green beans (FUKUSHIMA \& LANFER-MARQUEZ, 2000).

The drying methods are based on mechanisms that may reduce operating costs as well as energy consumption and time. However, specific techniques on crambe management need studies, therefore, the objective of this study was to evaluate the effect of different drying methods on the pigmentation of the grain and oil quality and biodiesel extracted from crambe.

\section{MATERIAL AND METHODS}

The study was conducted in the experimental field of Lageado farm belonging to the

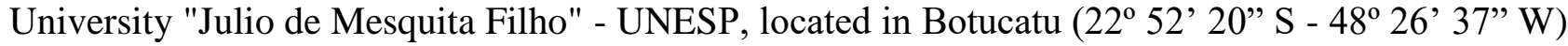
with altitude and slope average of 770 meters and $4.5 \%$, respectively, subtropical climate with hot, humid summers and cold, dry winters.

In this experiment were used for sowing $30 \mathrm{~kg} \mathrm{ha}^{-1}$ of crambe cultivar Bright FMS seeds, provided by the Mato Grosso do Sul Foundation, which were previously treated with fungicide (Carboxyl $200 \mathrm{~g} \mathrm{~L}^{-1}+$ Tiram $200 \mathrm{~g} \mathrm{~L}^{-1}$ ). Fertilization was performed in the planting furrow $24.5 \mathrm{~kg}$ $\mathrm{ha}^{-1}$ of nitrogen, $85.7 \mathrm{~kg} \mathrm{ha}^{-1}$ of phosphorus and $49 \mathrm{~kg} \mathrm{ha}^{-1}$ of potassium. 
Sowing was held in May and harvest in August, time when the average maximum and minimum temperatures were 13.4 and $27.0{ }^{\circ} \mathrm{C}$ respectively, and the average relative humidity was $49.83 \%$.

In this study it was used five drying systems, consisting of natural drying (in the plant) and artificial drying (heated air, natural air, shade and ground). The tests took place in the Products Processing Laboratory of the Department of Agricultural Engineering at the University of Agricultural Sciences UNESP - Botucatu.

The experimental design was completely randomized, with five treatments and four replications, totaling 20 plots.

Artificial drying with heated air - the seeds were dried on a prototype developed for the research. The prototype consists of four PVC columns with $0.8 \mathrm{~m}$ height and $0.15 \mathrm{~m}$ in length, where each replicate was placed in a column. The height of the grain mass was 0.60 meters.

Artificial drying with natural air - drying with natural air was carried out on a prototype developed for the research, with four PVC columns of $1.5 \mathrm{~m}$ high and $0.15 \mathrm{~m}$ in diameter. The height in the grain mass was $1.25 \mathrm{~m}$.

Artificial drying on the ground - drying on the ground, the beans were scattered on sobriety with a layer of $5 \mathrm{~cm}$ thick. The grains were tumbled four times a day, giving them the best way to sunlight, and at the end of each day, were stacked and covered with plastic sheet.

Artificial drying in the shade - the seeds were scattered on sombrite with a layer of only a grain and kept under roof, staying in the shade during the day and protected from the moisture overnight.

Natural drying in the plant - the plant drying was held in a reserved area of 0.5 ha in the production field, until the beans reach water content close to $10 \%$ w.b.

Table 1 shows the water content and drying time in each drying method.

TABLE 1. Initial and final mean values of water content (\% w.b.) and drying time (h) in crambe seeds in different drying conditions.

\begin{tabular}{lccc}
\hline \multirow{2}{*}{ Drying Methods } & \multicolumn{2}{c}{ Water content $(\%)$} & Drying \\
\cline { 2 - 3 } & Initial & Final & Time $(\mathrm{h})$ \\
\hline Artificial drying with heated air & 21.2 & 9.49 & 7.4 \\
Artificial drying with natural air & 21.0 & 6.12 & 88 \\
Artificial drying on the ground & 21.4 & 6.01 & 74 \\
Artificial drying in the shadow & 21.3 & 6.85 & 92 \\
Natural drying in the plant & 21.5 & 7.43 & 90 \\
\hline
\end{tabular}

The determination of the percentage of green beans was carried out by the color notation system by MUNSELL (1976), under natural light (daylight), by a single observer. Of each sample obtained by drying methods were randomly taken 50 grain, and their colors were compared with the Munsell color chart. After visual examination, the results were expressed in "Hue" (tint or hue determined by the wavelength), "Value" (value shows brightness or luminous intensity) and "Chroma" (color saturation). For this study, the letter used indicates that the "Hue" was the 5Y. Vertically, the colors become darker successively, from top to bottom of each chart, from a visible and equivalent manner, step to step. In the horizontal part, the increase in color saturation ("Chroma"), from left to right, being its scale shown at the bottom. The vertical scale on the left of the chart, value notation is indicated ("Value"), as shown in Figure 1.

The grains were classified in this study as "Values", which range from 8 to 4, and "Chroma" ranging from 4 to 6. The grains that had "Value" 8, regardless of Chroma notation "were considered absent of any pigment or green tint. The grains ranging in "Value" from 7 to 4, regardless of 
"Chroma" notation were considered green. Thus, the percentage of green beans was obtained considering any nuance of green.

As confirmation of color analysis by the MUNSELL chart (1976) biochemical analyzes of chlorophyll were conducted with characteristic pigment in green plants.

The analysis of chlorophyll content was held at Sensitive Devices Laboratory and Germination Laboratory of the Department of Botany of the Botucatu Biosciences Institute. The chlorophyll content $(a$ and $b$ ) in crambe grains was evaluated according to the methodology described by SIMS \& GAMON (2012). The preparation took place weighing between 0.020 and $0.05 \mathrm{~g}$ grains macerated in liquid nitrogen and adding acetone solution at $80 \%$ (80\% acetone and $20 \%$ Tris-buffered solution). The samples were then kept in freezer for an hour. Subsequently, they were placed in a refrigerated centrifuge $\left(4{ }^{\circ} \mathrm{C}\right)$ for 5 minutes, and spectrophotometric reading performed at the following wavelengths: Chlorophyll $a=663 \mathrm{~nm}$, and Chlorophyll $b=647 \mathrm{~nm}$. The chlorophyll content was determined by the equations:

$$
\begin{aligned}
& \text { Chlorophyll } a=0.01273 *(\mathrm{~A} 663)-0.000897 *(\mathrm{~A} 537)-0.003046 *(\mathrm{~A} 647) \\
& \text { Chlorophyll } b=0.02405 *(\mathrm{~A} 647)-0.004305 *(\mathrm{~A} 537)-0.005507 *(\mathrm{~A} 663)
\end{aligned}
$$
where,

A - value of the spectrophotometric reading.

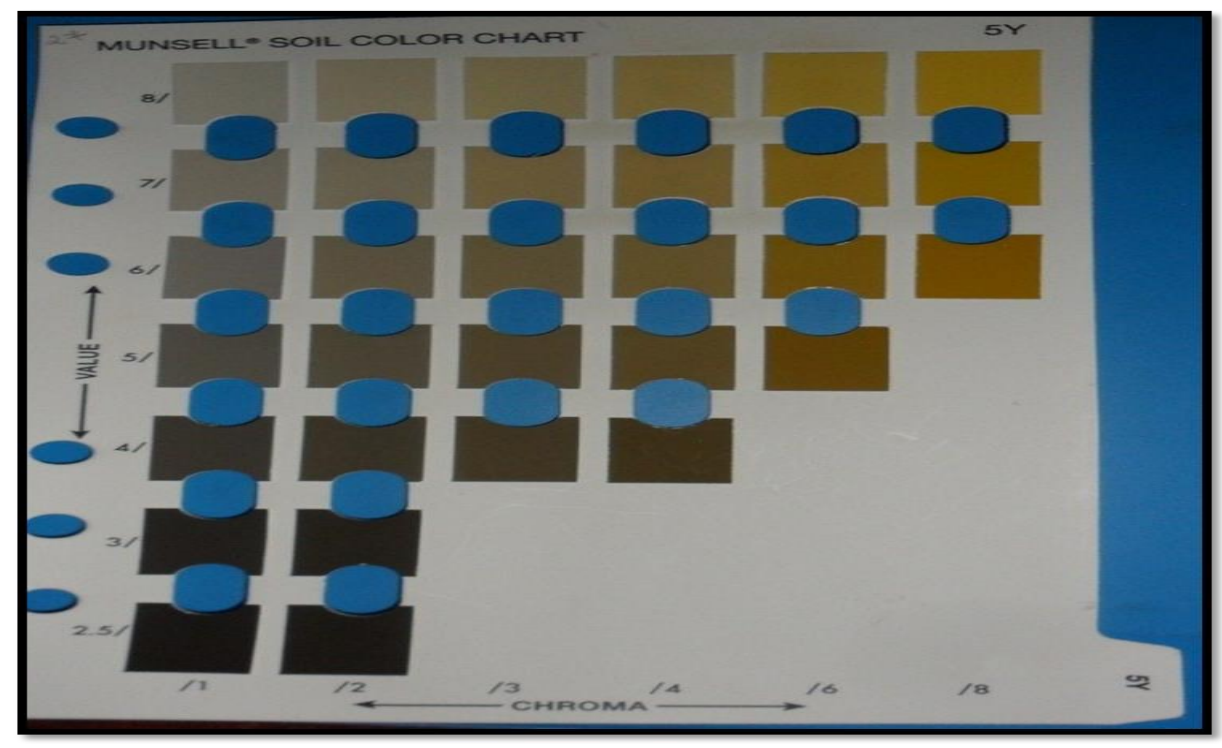

FIGURE 1. Munsell color chart used for visual classification of crambe green bean percentage (MUNSELL, 1976).

After drying, the beans were subjected to oil extraction by mechanical press. The oil extraction was performed in Botucatu Technology College (FATEC).

The oil content of crambe grains was performed by the chemical method of solvent extraction (AOCS, 1974). This analysis was performed by the Roots and Tropical Starches Center (CERAT, from the Universidade Estadual Paulista "Julio de Mesquita Filho", Botucatu.

Oil samples obtained by mechanical pressing were then forwarded to characterize the color, at the Monitoring and Research Center of Fuel, Biofuels, Oil Quality and Derivatives (CEMPEQC) from the Institute of Chemistry of the Universidade Estadual Paulista Estadual Paulista "Júlio de Mesquita Filho", Campus of Araraquara.

After the oil color analysis two treatments were selected, which were used to characterize the biodiesel. 
The biodiesel analyzes were: kinematic viscosity at $40{ }^{\circ} \mathrm{C}(\mathrm{NBR} 10,441)$, density at $20{ }^{\circ} \mathrm{C}$ (NBR 7,148), acid index (NBR 14,448), ester content (EN 14,103), iodine index (EN 14,111).

After obtaining the data, its homogeneity was observed (SHAPIRO-WILK test), then the results were submitted to analysis of variance, and when significant, the means were compared by $t$ test (LSD) $(\mathrm{p} \leq 0,05)$.

\section{RESULTS AND DISCUSSION}

Table 2 shows the features average values of the air in the dryer inlet duct in the artificial drying and ambient conditions in the drying methods without the use of dryers.

TABLE 2. Average values of the ambient temperature, temperature of the drying air in the inlet duct and in the grain mass, relative humidity $(\mathrm{RH})$ and air flow.

\begin{tabular}{|c|c|c|c|c|}
\hline \multirow{2}{*}{ Drying Methods } & \multicolumn{2}{|c|}{ Temperature $\left({ }^{\circ} \mathrm{C}\right)$} & \multirow{2}{*}{$\mathrm{RU}(\%)$} & \multirow{2}{*}{$\begin{array}{c}\text { Air flow } \\
\left(\mathrm{m}^{3} \mathrm{~min}^{-1} \mathrm{~m}^{-2}\right)\end{array}$} \\
\hline & Drying Air & Grain mass & & \\
\hline Artificial drying with heated air & 55.6 & 47.42 & $10.11+/-0.5$ & 17.6 \\
\hline \multirow[t]{2}{*}{ Artificial drying with natural air } & 27.0 & 24.05 & $50.2+/-0.5$ & 15.55 \\
\hline & Maximum & Minimum & & \\
\hline Artificial drying on the ground & 26.2 & 13.8 & $42.45+/-0.5$ & ------- \\
\hline Artificial drying in the shade & 24.7 & 12.9 & $45.27+/-0.5$ & -------- \\
\hline Natural drying in the plant & 27.0 & 13.4 & $49.83+/-0.5$ & ------- \\
\hline
\end{tabular}

In the drying method with heated air, the average temperature of the drying air was $55.6{ }^{\circ} \mathrm{C}$ and $61.0{ }^{\circ} \mathrm{C}$ the maximum. In the grains' mass, the temperature was $47.42{ }^{\circ} \mathrm{C}$ and $64.0{ }^{\circ} \mathrm{C}$ the maximum. The air flow was obtained by measuring the air speed with a propeller anemometer positioned on the prototype output, together with a reducing cone-making speed and the result found was $17.6 \mathrm{~m}^{3} / \mathrm{min} . \mathrm{m}^{2}$; and the average relative humidity reached $10.11 \%$.

As for the natural air drying, the average temperature in the inlet duct was $27.0{ }^{\circ} \mathrm{C}$ and 32.2 ${ }^{\circ} \mathrm{C}$ the maximum and the average in the grain mass was $24.05{ }^{\circ} \mathrm{C}$ and $33.9^{\circ} \mathrm{C}$ the maximum. The air flow was $15.55 \mathrm{~m}^{3} \mathrm{~min}^{-1} \mathrm{~m}^{2}$ and relative humidity was $50.2 \%$.

From the drying conditions (Table 2), as their effects on grain chlorophyll levels (Table 3 ), it was found that the highest content of chlorophyll $a$ was obtained in the drying with heated air, despite of do not differ statistically from natural drying air, shade and on the plant. For the Chlorophyll $b$ content, the highest value was also observed in the drying with heated air, although do not differ significantly from the drying with natural air and shade.

TABLE 3. Mean values of chlorophyll $a$ and $b\left(\mu \mathrm{g} \mathrm{g}^{-1}\right)$, green grains (\%) and oil content $(\%)$ obtained after each drying method.

\begin{tabular}{lcccc}
\hline \multicolumn{1}{c}{ Drying Methods } & Chlorophyll $a$ & Chlorophyll $b$ & Green beans & Oil content \\
\hline Artificial drying with heated air & $140.03 \mathrm{~b}$ & $211.20 \mathrm{c}$ & $48.75 \mathrm{~d}$ & $22.12 \mathrm{a}$ \\
Artificial drying with natural air & $131.26 \mathrm{ab}$ & $184.79 \mathrm{bc}$ & $28.75 \mathrm{c}$ & $28.92 \mathrm{c}$ \\
Artificial drying on the ground & $71.64 \mathrm{a}$ & $116.04 \mathrm{ab}$ & $19.50 \mathrm{~b}$ & $24.43 \mathrm{ab}$ \\
Artificial drying in the shade & $123.70 \mathrm{ab}$ & $195.44 \mathrm{bc}$ & $31.50 \mathrm{c}$ & $26.39 \mathrm{~b}$ \\
Natural drying in the plant & $78.98 \mathrm{ab}$ & $94.08 \mathrm{a}$ & $7.25 \mathrm{a}$ & $29.68 \mathrm{c}$ \\
\hline F & $2.32^{*}$ & $3.16^{*}$ & $234.660^{*}$ & $15.096^{*}$ \\
\hline C.V. $(\%)$ & 33.39 & 32.13 & 7.38 & 6.13 \\
\hline
\end{tabular}

* Significant $(\mathrm{p} \leq 0.05) ;$ C.V.: Coefficient of variation

Means followed by the same letter do not differ by $\mathrm{t}$ test $(\mathrm{P} \leq 0.05)$. 
Regarding green beans, it was found the highest percentage in the drying with heated air, while the lowest percentage was obtained by the drying on the plant (Table 3), assuming that this drying method, the chlorophyll degradation has been benefited by the presence of sunlight, whereas at high temperature, to be a faster process, there was no degradation of the green pigment during the grains drying.

In the drying on the ground, it was obtained the second lowest percentage of green beans, suggesting the influence of solar radiation on the chlorophyll degradation in the grains, as also, this drying system has received much direct sunlight. The highest oil content was found in the drying with natural air and in the plant.

In the drying with heated air was observed the highest percentage of green beans. The drying at high temperature retains the grains chlorophyll, because to occur very quickly, prevents the green pigment degradation. In the drying methods with natural air and in the shade, it was obtained the second highest percentage of green beans. Drying with natural air, the average temperature in the grains' mass was $24.05{ }^{\circ} \mathrm{C}$, according to FUKUSHIMA \& LANFER -MARQUEZ (2000), temperatures around $25{ }^{\circ} \mathrm{C}$ favor the degradation of the chlorophyll, a factor that may explain the presence of minor green beans in the drying with natural air, compared with the drying with heated air have even occurred without the influence of solar radiation.

In a study of coriander seeds in different types of drying (fixed bed dryer and freeze drier at $25{ }^{\circ} \mathrm{C}$ ) treatments promoted chlorophyll degradation as due to temperature exposure and / or oxygen, though the contents of chlorophyll $a$ and $b$ were higher in dry coriander in dryer at $50{ }^{\circ} \mathrm{C}$, the temperature at which it was exposed during drying coriander concentrated pigment chlorophyll and favored the pigmentation of the product (SANTOS et al., 2012).

The crambe cultures, in particular the studied cultivar Brilliant FMS presents irregular maturation and in this way was obtained mature and immature grains on the same plant. Thus, at the time of harvest, the machine has no way to separate mature and immature grains, culminating in a high percentage of green grains in harvested material.

It is observed in this study, that the grains dried in the presence of sunlight obtained different color from the ones dried artificially, in the absence of light (Table 3).

Likewise, the dried grain in the presence of sunlight (artificial drying on the ground and drying on the plant) had higher levels of chlorophyll $a$ and $b$, while the dried beans without the presence of sunlight showed lower levels. It can be stated that in crambe, the presence of sunlight promotes the degradation of chlorophyll, minimizing the presence of green beans, while the absence of sunlight promotes its retention. The isolate content of chlorophyll $a$ and $b$ and percentage of green beans were higher in the drying at high temperature, and lower in the drying in the plant, which confirms that drying at high temperature favors the retention of chlorophyll, whereas drying in the plant favors its degradation.

As for the oil extracted from the beans, this presented greenish yellow coloration in the drying process with natural air and in the shade; comparing the oil from dried grains on the ground it was clear in relation to the turbid yellow-colored oil extracted from grains dried naturally in plants (Figure 2). In this comparison, there was a green color in the oil extracted from the beans submitted to drying with heated air (Figure 2). 


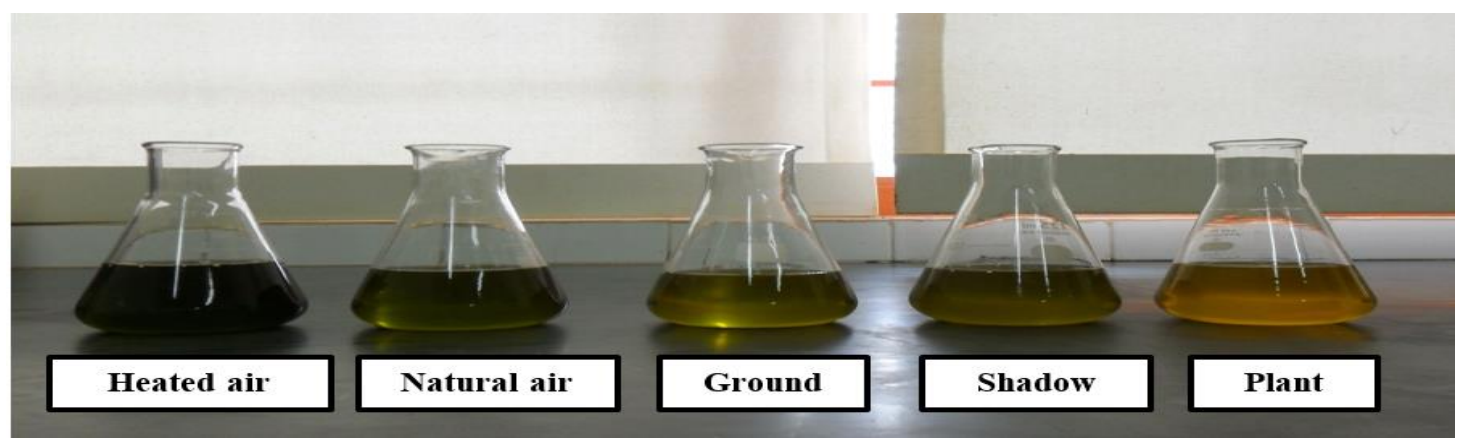

FIGURE 2. Colors of crude oil extracted from crambe grains in each drying method.

According to FUKUSHIMA \& LANFER -MARQUEZ (2000), drying at high temperature above $40^{\circ} \mathrm{C}$ causes chlorophyll retention in grains, which remain green, reflecting in oil color, justifying the high rate of green beans in dry samples with heated air (Table 3) as well as oil color (Table 4).

TABLE 4. Color classification of crude oil extracted from crambe grains in each drying method.

\begin{tabular}{ll}
\hline Drying Methods & Color \\
\hline Artificial drying with heated air & Green \\
Artificial drying with natural air & Yellow green \\
Artificial drying on the ground & Limpid greenish yellow \\
Artificial drying in the shade & Yellow green \\
Natural drying in the plant & Yellow turbid \\
\hline
\end{tabular}

In the drying that took place under the direct action of sunlight, it was observed oil bleaching. Thus, drying on the ground, the oil showed clear greenish yellow color, while in the drying in the plant, the grains dried with lower content of green due to the higher chlorophyll degradation allowed the extraction of the oil with turbid yellow color.

Table 5 presents a characterization of biodiesel obtained from the dried grains in the drying systems with heated air and in the plant, the two treatments that more polarized as the crude oil coloring.

TABLE 5. Characterization of biodiesel from crambe (Crambe abyssinica Hochst) in the plant drying method and heated air method and limits of the National Petroleum Agency (ANP).

\begin{tabular}{lccc}
\hline Features and Variables & Plant & Heated air & ANP limits \\
\hline Kinematic Viscosity at $40^{\circ} \mathrm{C}\left(\mathrm{mm}^{2} \mathrm{~s}^{-1}\right)$ & 6.0 & 6.1578 & $3.0-6.0$ \\
Specific mass at $20^{\circ} \mathrm{C}\left(\mathrm{kg} \mathrm{m}^{-3}\right)$ & 873.5 & 873.3 & $850-900$ \\
Acidity Index $\left(\mathrm{mg} \mathrm{KOH} \mathrm{g}^{-1}\right)$ & 0.0698 & 0.0744 & 0.5 \\
Ester content $(\%$ massa) & 85.77 & 85.26 & 96.5 \\
Iodine index $\left(\mathrm{gI}_{2} 100 \mathrm{~g}^{-1}\right)$ & 87.692 & 88.024 & ------ \\
\hline
\end{tabular}

Source limits of ANP:

http://nxt.anp.gov.br/nxt/gateway.dll/leg/resolucoes_anp/2012/maio/ranp\%2014\%20-\%202012.xml 
The values of density at $20{ }^{\circ} \mathrm{C}$ can vary from 850 to $900 \mathrm{~kg} \mathrm{~m}^{-3}$, the two drying systems met, leaving $873.5 \mathrm{~kg} \mathrm{~m}^{-3}$ in the drying in the plant and $873.3 \mathrm{~kg} \mathrm{~m}^{-3}$ with the drying with heated air.

According to the rules established by the National Petroleum Agency (ANP), the kinematic

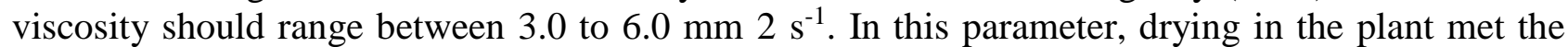
requirements, leaving $6.0 \mathrm{~mm} 2 \mathrm{~s}^{-1}$ however; drying with heated air was higher, reaching 6.1578 $\mathrm{mm} 2 \mathrm{~s}^{-1}$.

For the acidity index (Table 5), the maximum limit of $0.5 \mathrm{mg} \mathrm{KOH} \mathrm{g}^{-1}$ was not overcome by the drying in the plant and heated air that record $0.0698 \mathrm{KOH} \mathrm{g}^{-1}$ and $0.0744 \mathrm{KOH} \mathrm{g}^{-1}$, respectively, remaining within the maximum values required.

The maximum ester content (mass \%) of 96.5 was also not exceeded, and the drying in the plant was $85.77 \%$ mass, and drying with heated air $85.26 \%$ mass. For iodine index, the ANP does not provide the limits, drying in the plant had $87.692 \mathrm{gI}^{2} 100 \mathrm{~g}^{-1}$ and drying with heated air 88.024 gI2 $100 \mathrm{~g}^{-1}$ (Table 5).

GALLINA et al. (2011), evaluating soy biodiesel, canola and sunflower, obtained density values close to this study being them equal to $878.9 ; 877.3$ and $872.2 \mathrm{~kg} \mathrm{~m}^{-3}$ respectivily (Table 5), all within the limits allowed for B-100 biodiesel by ANP. For biodiesel color, the same authors classified for soybeans, light yellow; canola, dark yellow and dark yellow for sunflower.

OLIVEIRA et al. (2012), evaluating the acidity index in moringa biodiesel, found value of 0.5 $\mathrm{mg}$ of $\mathrm{KOH} \mathrm{g}{ }^{-1}$, as the values obtained in this study, whose values are presented in accordance with the rules of the ANP. The same authors found that the kinematic viscosity of moringa biodiesel is equivalent to $13.56 \mathrm{~mm}^{2} \mathrm{~s}^{-1}$ being outside the limits of the ANP, unlike crambe biodiesel results in this study, where the highlighted values were close to those set by the same agency.

In crambe biodiesel, JASPER et al. (2010) found acidity index of $0.06 \mathrm{mg} \mathrm{KOH} \mathrm{g}^{-1}$, iodine index of $88 \mathrm{gl} 2100 \mathrm{~g}^{-1}$, ester content of $96.5 \%$ mass, density at $20{ }^{\circ} \mathrm{C}$ of $874 \mathrm{~kg} \mathrm{~m}^{-3}$, kinematic viscosity at $40{ }^{\circ} \mathrm{C}$ of $5.919 \mathrm{~mm}^{2} \mathrm{~s}^{-1}$, all of which are close to those found in this study (Table 5).

In commercial scale, crambe oil can be used for biodiesel production because it meets the standards of the National Petroleum, Natural Gas and Biofuels (ANP).

\section{CONCLUSIONS}

It is concluded from the results that although there was variation in the color of grain and oil due to the drying method, the quality of the biodiesel met the standards.

\section{REFERENCES}

AOCS. Official methods and recommended practices of the american oil chemists society. Champaign, 1974. 111p.

BRANDÃO, F.J.B.; SILVA, A.R.B.; SILVA, M.A.P.; SPEROTTO, F.C.S. Desempenho operacional e produtividade agrícola do crambe nos preparos convencional e reduzido de solo. Enciclopédia Biosfera, Goiânia, Centro Científico Conhecer, v.9, n.17; p.1009-1019, nov./dez. 2013.

BRASIL. Anuário Estatístico Brasileiro do Petróleo, Gás Natural e Biocombustíveis /Agência Nacional do Petróleo, Gás Natural e Biocombustíveis. Rio de Janeiro: ANP, 2012.

COLODETTI, T.V.; MARTINS, L.D.; Rodrigues, W.N.; Brinate, S.V.B.; Tomaz, M.A.Crambe: Aspectos Gerais da Produção Agrícola. Enciclopédia Biosfera, Centro Cientifico Conhecer, Goiânia, v.8, n.14, p. 258-269. jun. 2012.

DELALIBERA, H. C.; CAMPOLINA, N.; WEIRICH NETO, P. H.; RALISCH, R. Performance of a diesel engine fueled with a preheated blend of soybean oil and petrodiesel. Engenharia Agrícola, Jaboticabal, v.32, n.6, p.1058-1067, nov./dez. 2012. Disponível em:

<http://www.engenhariaagricola.org.br>. doi: 10.1590/S0100-69162012000600007. 
FUKUSHIMA, P.S.; LANFER-MARQUEZ, U.M. Chlorophyll derivatives of soybean during maturation and drying conditions. In: INTERNATIONAL SOYBEAN AND PROCESSING AND UTILIZATION CONFERENCE, 3., 2000, Tukuba. Proceedings ...Tukuba: Korin, 2000. p.87-88.

GALLINA, A.L.; FOLQUENIN, E.K.F.; BANCZEK, E do P.; CUNHA, M.T. da; BORGES, C. P.F. Obtenção e caracterização físico-química do Biodiesel B100 e de misturas Biodiesel/Diesel. Revista Ciências Exatas e Naturais, Guarapuava, v.13, n.2, p. 211-226, jul./dez. 2011.

OLIVEIRA, D.S.; FONSECA, X.D.S.; FARIAS, P.N.; BEZERRA, V.S.; PINTO, C.H.C.; SOUZA, L.D.; SANTOS, A.G.D.; MATIAS L.G.O. Obtenção do biodiesel através da transesterificação do óleo de moringa oleifera lam. HOLOS, Natal, v.1, p.45-61, jan./mar. 2012.

Disponível em: <http://www2.ifrn.edu.br/ojs/index.php/HOLOS/article/view/803〉. _ doi: 10.15628/holos.2012.803

JASPER, P.A.; BIAGGIONI, M.A.M, SILVA, P.R.A.; SEKI, A.S.; BUENO, C.O. Análise Energética da Cultura do Crambe (Crambe abyssinica Hochst) produzida em Plantio Direto. Engenharia Agrícola, Jaboticabal, v.30, n.3, p.395-403, maio/jun. 2010.

Disponível em: <http://www.engenhariaagricola.org.br> doi: 10.1590/S0100-69162010000300004

MUNSELL, A. H. Munsell book of color. Baltimore: Macbeth Division of Kollmorgen, 1976.(Mathefinish collection).

OLIVA, A.C.E. de; BIAGGIONI, M. A. M.; CAVARIANI, C. Efeito imediato do método de secagem na qualidade de sementes de crambe. Energia na Agricultura, Cascavel, v.27, n.3, p.16-30. jul./set. 2012. Disponível em: <http://revistas.fca.unesp.br/index.php/energia>. doi:

10.17224/EnergAgric.2012v27n3p16-30

PÁDUA, G.P.; FRANÇA-NETO, J.B.; CARVALHO, M.L.M.; KRZYZANOWSKI, F.C.;

GUIMARÃES, R.M. Incidence of green soybean seeds as a function of environmental stresses during seed maturation. Revista Brasileira de Sementes, Londrina, v.31, n.3, p.150-159, ago./set. 2009a.

Disponível em: <http://www.scielo.br/scielo.php?script=sci_serial\&pid=0101-

3122\&lng=en\&nrm=iso>. doi: 10.1590/S0101-31222009000300017

PÁDUA, G.P.; CARVALHO, M.L.M.; FRANÇA-NETO, J.B.; GUERREIRO, M.C.; GUIMARÃES, R.M. Response of soybean genotypes to the expression of green seed under temperature and water stresses. Revista Brasileira de Sementes, Londrina, v.31, n.3, p.140-149, ago./set. 2009b. Disponível em: 〈http://www.scielo.br/scielo.php?script=sci_serial\&pid=0101-3122\&lng=en\&nrm=iso >. doi: 10.1590/S0101-31222009000300016

PITOL, C.; BROCH, D. L.; ROSCOE, R. Tecnologia e produção: crambe 2010. Maracajú: Fundação MS, 2010.

ROCHA, C.; GOMES, B.M.; GOMES, S.D.; SENE, L.; ZENATTI, D.C. Selection of microornismis producer of lipase for fat removal from biodiesel purification water. Engenharia Agrícola, Jaboticabal, v.33, n.2, p.332-340, mar./abr. 2013. Disponível em: <http://www.engenhariaagricola.org.br>. doi: $10.1590 / \mathrm{S} 0100-69162013000200012$

SANTOS, G.; OLIVEIRA, M. C.; MORAES, M. H.; PAGANI, A. A. C. Estudo comparativo do coentro (Coriandum Sativum 1.) seco obtido em diferentes métodos de secagem, Revista GEINTEC, Aracajú, v.2, n.3, p.236-244. 2012. Disponível em:

http://www.revistageintec.net/portal/index.php/revista >. doi: 10.7198/S2237-0722201200030004

SILVA, M.A.P.; BIAGGIONI, M.A.M.; SPEROTTO, F.C.S.; BEZERRA, P.H.S.; BRANDÃO, F.J.B. Qualidade do óleo bruto de grãos de crambe (Crambe abyssinica Hochst) sob diferentes métodos de secagem. Energia naAgricultura, Cascavel, v.28, n.3, p.193-199, jul./set. 2013.

Disponível em: <http://revistas.fca.unesp.br/index.php/energia>. doi: 10.17224/EnergAgric.2013v28n3

SIMS, D.A., GAMON, J.A. Relationships between leaf pigment content and spectral reflectance across a wide range of species, leaf structures and developmental stages. Remote Sensing of Environment, Reading, v.31, n.3, p.37-354, ago. 2012.

Disponível em: <http://www.journals.elsevier.com/remote-sensing-of-environment>. doi:10.1016/S0034-4257(02)00010-X 